\title{
Antifungal, antibiofilm, and antiproliferative activities of Guapira graciliflora Mart
}

Carolina Medeiros de ALMEIDA ${ }^{(a)}$

Rennaly de Freitas LIMA(a)

Tereza Karla Vieira Lopes da COSTA ${ }^{(a)}$

Ilza Maria de Oliveira SOUSA(b)

Elaine Cristina CABRAL(b)

Rosanna Tarkany BASTING(b)

Adriana Della TORRE(b)

Yuri Wanderley CAVALCANTI(c)

Pedro Luiz ROSALEN(d)

Marta Cristina Teixeira DUARTE(b)

Ana Lúcia Tasca Gois RUIZ(b)

Mary Ann FOGLIO(b)

Gustavo Pina GODOY(a)

Edja Maria Melo de Brito COSTA ${ }^{(a)}$

(a) Universidade Estadual da Paraíba - UEPB, Department of Dentistry, Campina Grande, PB, Brasil.

(b) Universidade Estadual de Campinas - Unicamp, Chemical, Biological and Agricultural Pluridisciplinary Research Center, Campinas, SP, Brazil.

(c)Universidade Federal da Paraíba - UFPB, Department of Dentistry, Campina Grande, PB, Brasil.

(d) Universidade Estadual de Campinas - Unicamp, Piracicaba Dental School, Department of Physiological Sciences, Piracicaba, SP, Brazil.

Declaration of Interests: The authors certify that they have no commercial or associative interest that represents a conflict of interest in connection with the manuscript.

\section{Corresponding Author:}

Carolina Medeiros de Almeida

E-mail: ccarol_21@hotmail.com

https://doi.org/10.1590/1807-3107bor-2018.vol32.0041

Submitted: July 18, 2017

Accepted for publication: Mar 08, 2018

Last revision: Apr 05, 2018
Abstract: The aim of this study was to evaluate in vitro the antifungal, antibiofilm and antiproliferative activities of the extract from the leaves of Guapira graciliflora Mart. The phytochemical characterization of the extract was performed using electrospray ionization mass spectrometry (ESI-MS). The antimicrobial activity of the extract and its fractions was evaluated using the broth microdilution method against species of Candida. The inhibition of C. albicans biofilm was evaluated based on the number of colony-forming units (CFU) and metabolic activity (MTT). The antiproliferative activity of the extract and its fraction was evaluated in the presence of human tumor and non-tumor cells, and the cytotoxicity of the extract was determined on the RAW 264.7 macrophage line - both using the sulforhodamine B method. The phytochemical characterization indicated the presence of the flavonoids rutin and kaempferol. The extract and the methanol fraction exhibited moderate antifungal activity against $C$. albicans, C. krusei, and C. glabrata, and strong activity against $C$. dubliniensis. In the biofilms at 24 and 48 hours, the concentration of $12500 \mu \mathrm{g} / \mathrm{mL}$ of the extract was the most effective at reducing the number of CFU s/mL $(44.4 \%$ and $42.9 \%$, respectively) and the metabolic activity of C. albicans cells (34.6\% and $52 \%$, respectively). The extract and its fractions had no antiproliferative effect on the tumor lines tested, with mean activity (log GI50) equal to or greater than $1.71 \mu \mathrm{g} / \mathrm{mL}$. Macrophage cell viability remained higher than $80 \%$ for concentrations of the extract of up to $62.5 \mu \mathrm{g} / \mathrm{mL}$. G. graciliflora has flavonoids in its chemical composition and demonstrates potential antifungal and antibiofilm activity, with no evidence of a significant change in the viability of human tumor and non-tumor cell lines.

Keywords: Plants, Medicinal; Nyctaginaceae; Candida; Biofilms.

\section{Introduction}

Oral candidiasis is a mucocutaneous mycosis caused by yeasts of the genus Candida, especially Candida albicans. ${ }^{1}$ Species of Candida are normally present in the microbiota of the oral cavity and their transition into a pathogenic form occurs when their virulence factors predominate in relation to the host defense mechanisms, giving rise to infection. ${ }^{2}$ Predisposing factors for oral candidiasis include systemic diseases, immunodeficiency, broad-spectrum antibiotic therapy, reduced salivary flow, nocturnal use of poorly cleaned dentures, and smoking. ${ }^{3}$ 
The incidence of candidiasis in recent years has become a public health concern, which may have stemmed from the growing number of immunocompromised individuals, the widespread use of broad-spectrum antibiotics, and the increase in the prevalence of candidiasis caused by non-albicans species, such as Candida glabrata, Candida tropicalis, Candida krusei, and Candida parapsilosis. These species are more closely related to a higher mortality rate and antifungal resistance than $C$. albicans. ${ }^{4}$

Antifungal agents available on the market are effective, but have side effects, such as allergic reactions and adverse interactions with medications. ${ }^{5}$ Moreover, the emergence of resistant strains has led to serious, persistent infections. Thus, the search for effective therapeutic alternatives of microbiological control for use on humans ${ }^{6}$ has led to a growing interest in medicinal plants due to their therapeutic potential for the development of new effective drugs with fewer undesirable effects in comparison to existing drugs, providing healthcare professionals with viable options for the treatment of oral diseases. ${ }^{2}$ This possibility has motivated the investigation of the chemical composition of medicinal plants used by the population, which can lead to the discovery of compounds with therapeutic potential. ${ }^{7}$

Among the biodiversity studied, Guapira graciliflora Mart. belongs to the family Nyctaginaceae. This shrub is commonly found in the semiarid caatinga biome of Northeastern Brazil and is widely used as a medicinal plant by the local population ${ }^{8}$ due to its anti-tuberculosis, anti-inflammatory, and healing activities. ${ }^{9}$

The aim of the present study was to perform an in vitro evaluation of the antifungal, antibiofilm, and antiproliferative activities of an extract made from the leaf of G. graciliflora Mart.

\section{Methodology}

\section{Preparation of the extract and fractioning}

Leaves of Guapira graciliflora Mart. were collected in the month of August in the municipality of Queimadas, located in the micro-region Eastern Cariri, in the meso-region of Borborema and in the semi-arid region of the state of Paraíba in Northeastern Brazil. A voucher specimen was deposited in the collection of the Manuel de Arruda Câmara Herbarium of the Status University of Paraíba, Campus I, in Campina Grande, Paraíba, under register $n^{\circ}$ 907/ACAM.

The leaves (200 g) were dried, ground, and immersed in 50\% ethanol ( $1 \mathrm{~L}$ ) for 48 hours. The mixture was then filtered and the residue was immersed in 50\% ethanol two more times. The three final phases were vacuum-concentrated (Quimis ${ }^{\circledR}$ / Q344 M,) and freeze-dried (Labconco ${ }^{\circledR} /$ Freezone 4.5).

The chemical compounds of the extract were initially monitored by thin-layer chromatography (TLC), using aluminum chromatoplates with a silica stationary phase (TLC silica gel $60 \mathrm{~F}_{254}$ - Merck) and mobile phase of ethyl acetate, formic acid, acetic acid, and water (100:11:11:26). The labeling of the chemical components of the sample was viewed under ultraviolet light (264 and $365 \mathrm{~nm}$ ) and the chromatoplate was developed with anisaldehyde, with subsequent heating at $100^{\circ} \mathrm{C}$ for one minute. For the fractioning of the extract, solid-liquid partitioning was performed in a filtering chromatographic column with a porous plate funnel in accordance with the polarity gradient: hexane, dichloromethane, dichloromethane:methanol (95:5, 90:10, 50:50), methanol. and methanol:water (50:50). The resulting fractions were monitored by TLC and reunited based on the similarity profile and colorations in the presence of the developer, followed by vacuum concentration (BUCHI Rotavapor ${ }^{\circledR}$ R-215). Three final fractions (methanol fraction, methanol sub-fraction, and hydromethanol fraction [50:50]) that contained the labeling of the compounds of interest were obtained and reunited based on the similarity profile and colorations in the presence of the developer employed. The fractions were used for the evaluation of antimicrobial and antiproliferative activities, not for antibiofilm activity.

\section{Phytochemical characterization}

The phytochemical analysis of the extract was performed using electrospray ionization mass spectrometry (ESI-MS). The extract $(10 \mathrm{mg})$ was dissolved in $1 \mathrm{~mL}$ of the appropriate solvent, and $10 \mu \mathrm{L}$ 
of the resulting solution was diluted in $990 \mu \mathrm{L}$ of a methanol $/ \mathrm{H}_{2} \mathrm{O}$ mixture $(1: 1, \mathrm{v} / \mathrm{v})$ with $0.1 \%$ auxiliary additives, following the ionization method. The auxiliary additives that favor ionization are formic acid $(99 \%)$ or ammonium hydroxide (25\%) used for ESI (+) or ESI (-), respectively, at a concentration of $0.1 \%$. The sample solutions were injected by direct insertion into the mass spectrometer (7.2 T LTQ-FT Ultra, Thermo Scientific, Germany). The total time for the acquisition of each spectrum was fixed at one minute. The ESI-MS and ESI-MS/MS spectra were acquired in negative ionization mode. The full-scan spectra were acquired in the range of $\mathrm{m} / \mathrm{z} 150$ to 2000 and the ESI-MS/MS spectra were acquired beginning at $m / z 50$ to a value slightly above the ion in question and with a collision energy of 10 to $40 \mathrm{eV}$. The spectra were treated with the specific software program of the mass spectrometer (Xcalibur 2.0, Thermo Scientific, Germany) $)^{10}$.

\section{Antifungal activity}

The antimicrobial potential of the extract and selected fractions was analyzed in the presence of Candida species (C. albicans ATCC 10231; C. glabrata CBS 07; C. krusei CBS 573; and C. dubliniensis CBS 7889) using the broth microdilution method, with the determination of the minimum inhibitory concentration (MIC) and minimum fungicidal concentration (MFC) following the norms established by the Clinical and Laboratory Standards Institute. ${ }^{11}$ The G. graciliflora extract and fractions were diluted in RPMI-1640 culture medium (Angus Buffers \& Biochemicals, Niagara Falls, NY, USA) and 10\% dimethyl sulfoxide (DMSO) (Sigma-Aldrich ${ }^{\circledR}$ ). The assay was performed in 96-well microplates containing $100 \mu \mathrm{L} /$ well of RPMI-1640 culture medium. One hundred microliters of the test samples was added to the initial well $(8 \mathrm{mg} / \mathrm{mL})$, followed by serial microdilution, obtaining concentrations between 2000 and $0.4882 \mu \mathrm{g} / \mathrm{mL}$.

To prepare the yeast suspension, 24-hour yeast cultures were added in $5 \mathrm{~mL}$ of sterile saline solution ( $\mathrm{NaCl} 0.9 \%$ ), adjusting its absorbance between 0.08 to 0.10 at $530 \mathrm{~nm}$ to obtain a density equivalent to $5.0 \times 10^{6} \mathrm{CFU} / \mathrm{mL}$. From this suspension, serial dilutions were performed in RPMI-1640 culture medium, obtaining a final density of $5.0 \times 10^{3} \mathrm{CFU} / \mathrm{mL}$. In the wells of the microplate, the final solution resulted in a concentration of $2.5 \times 10^{3} \mathrm{CFU} / \mathrm{mL}$.

Next, $100 \mu \mathrm{L}$ of yeast suspension was added to each well. The plates were incubated for 48 hours at $37^{\circ} \mathrm{C}$. Nystatin $(0.5 \mathrm{mg} / \mathrm{mL})\left(\right.$ Sigma-Aldrich $\left.{ }^{\circledR}\right)$ was used as the positive control. The MIC was defined as the lowest concentration of the sample capable of inhibiting visible microbial growth, as confirmed by the change in the color of the RPMI-1640 medium. The MIC categories proposed by Holetz et al. ${ }^{12}$ were used for the classification of the antimicrobial activity of the extract and its fractions: $<100 \mu \mathrm{g} / \mathrm{mL}=$ strong activity; between 100 and $500 \mu \mathrm{g} / \mathrm{mL}=$ moderate activity; between 500 and $1000 \mu \mathrm{g} / \mathrm{mL}=$ weak activity; and $>1000 \mu \mathrm{g} / \mathrm{mL}=$ no activity.

For the determination of the MFC, an aliquot of $50 \mu \mathrm{L}$ from each well with concentrations equal to or higher than the MIC was sub-cultivated in Sabouraud Dextrose Agar medium $\left(\right.$ Merck $\left.^{\circledR}\right)$ and incubated at $37^{\circ} \mathrm{C}$ for 48 hours. The MFC was defined as the smallest concentration that inhibited visible growth. The assays were performed in duplicate and in two separate experiments.

\section{Inhibition of biofilm formation}

Chemically polymerized, colorless acrylic resin discs (10 $\mathrm{mm}$ diameter and $2 \mathrm{~mm}$ thickness) were prepared according to the manufacturers' instructions. Discs were finished using a horizontal polisher (model APL-4; Arotec, São Paulo, Brazil) with progressively finer aluminum oxide sanding paper (320-, 400-, and 600-grit). The surface roughness was standardized to $0.30 \pm 0.02 \mu \mathrm{m}$. Prior to use, acrylic discs were ultrasonically cleaned with $70 \%$ (v/v) alcohol and sterile ultra-purified water $(20 \mathrm{~min})$ to remove surface debris. The discs were immersed in a sodium hypochlorite solution $(2 \mathrm{~g} / \mathrm{L})$ for 5 minutes and then thoroughly rinsed with sterile water. Discs were maintained in sterile distilled water until use.

C. albicans 10231 culture was subcultured on Sabouraud Dextrose Agar (Merck ${ }^{\circledR}$ ) plates incubated at $37^{\circ} \mathrm{C}$ for 24 hours. Then, the cells were resuspended in Sabouraud Dextrose Broth (Himedia ${ }^{\circledR}$ ). The concentration of the yeast suspension was determined 
in a Neubauer Chamber (KASVI $\left.{ }^{\circledast}\right)$ to obtain a cell density of $2 \times 10^{5} \mathrm{CFU} / \mathrm{mL}$.

The discs were individually placed in the wells of a 24-well plate (KASVI ${ }^{\circledR}$ 24-Well Tissue Culture Plate) containing $1 \mathrm{~mL}$ of the C. albicans suspension and $1 \mathrm{~mL}$ of the extract diluted in Sabouraud Dextrose Broth (supplemented with 1\% glucose, obtaining the following final concentrations of extract, based on the minimum inhibitory concentration's value: 125 (MIC), 1250 (10 x MIC), and 12500 (100 x MIC) $\mu \mathrm{g} / \mathrm{mL}$. The plates were incubated for two hours with $75 \mathrm{rpm}$ orbital shaking at $37^{\circ} \mathrm{C}\left(\mathrm{LABOR}^{\circledR}\right.$ SP-200). Nystatin $100 \mu \mathrm{g} / \mathrm{mL}$ (Sigma-Aldrich ${ }^{\circledR}$ ) was used as the positive control. The discs were then transferred to a new 24-well plate $\left(\mathrm{KASVI}^{\circledR}\right.$ 24-Well Tissue Culture Plate) containing $2 \mathrm{~mL} /$ well of Sabouraud Dextrose Broth supplemented with $1 \%$ glucose and incubated for 24 and 48 hours at $37^{\circ} \mathrm{C}$. After each period, the discs were gently washed in $0.9 \%$ saline solution to remove non-adhered cells, and then transferred to tubes containing $2 \mathrm{~mL}$ of a new $0.9 \%$ saline solution in which the biofilm was removed from the discs with the aid of a tube shaker $\left(\mathrm{KASVI}^{\circledR}\right.$, Vortex Mixer K45-2810) for 30 seconds, obtaining a biofilm suspension, which was used for the quantification of viable cells (CFU/mL) and evaluation of the metabolic activity of C. albicans. ${ }^{13}$ The assays were performed in triplicate and in three separate experiments.

\section{Quantification of viable cells}

The biofilm suspension was submitted to serial dilutions $\left(10^{-1}, 10^{-2}, 10^{-3}, 10^{-4}, 10^{-5}\right.$, and $\left.10^{-6}\right)$. One aliquot $(10 \mu \mathrm{L})$ of each dilution was plated in triplicate in Sabouraud Dextrose Agar medium. The plates were incubated at $37^{\circ} \mathrm{C}$ for 48 hours (LABOR ${ }^{\circledR} \mathrm{SP}-200$ ). The $\mathrm{CFU}$ were counted and the results were reported as $\mathrm{CFU} / \mathrm{mL}^{13}$

\section{Metabolic activity}

The metabolic activity of the cells was determined using the MTT [3-(4,5-dimethylthiazol2-yl)-2,5-diphenyltetrazolium bromide] method (Sigma-Aldrich $^{\circledast}$ - Thiazolyl Bromide Tetrazolium Blue). A volume of $1 \mathrm{~mL}$ of solution containing cells from the residual biofilm was centrifuged (KASVI ${ }^{\circledR}$, K14-0602) at $1500 \mathrm{rpm}$ for 5 minutes. The supernatant was discarded and $200 \mu \mathrm{L}$ of MTT solution was added to the pellet at a concentration of $0.5 \mathrm{mg} / \mathrm{mL}$. The cells were incubated for three hours at $37^{\circ} \mathrm{C}\left(\mathrm{LABOR}^{\circledR}\right.$ SP-200). The supernatant was discarded and $200 \mu \mathrm{L}$ of isopropyl alcohol were added to the cells. The cells were incubated again at $37^{\circ} \mathrm{C}$ for 15 minutes on an orbital shaker. Absorbance was read using a microplate reader (Biochrom ${ }^{\circledR}$, EZ Reader 400 Microplate Reader) at a wavelength of $570 \mathrm{~nm} .{ }^{14}$

\section{Antiproliferative assay}

The antiproliferative activity of the G. graciliflora extract and its fractions was evaluated using human tumor cells lines (U251 [glioma], MCF-7 [breast], NCI-ADR/RES [resistant ovary], 786-0 [kidney], NCI-H460 [lung], PC-3 [prostate], and HT-29 [colon]) and a non-tumor line (HaCat [keratinocyte]). Cell suspensions were prepared in RPMI-1640 medium with the addition of $5 \%$ fetal bovine serum (Gibco-BRL, Grand Island, NY, USA) and 1\% penicillin:streptomycin. The suspensions were adjusted to their respective densities, placed in 96-well plates $(100 \mu \mathrm{L} /$ well $)$, and exposed to the extract and its fractions $(0.25,2.5,25$, and $250 \mu \mathrm{g} / \mathrm{mL})$ diluted with 10\% DMSO (Sigma-Aldrich, St. Louis, $\mathrm{MO}, \mathrm{USA})$, remaining at $37^{\circ} \mathrm{C}$ for 48 hours in a humid atmosphere with $5 \% \mathrm{CO}_{2}$ (Forma Scientific ${ }^{\circledR}, \mathrm{CO}_{2}$ Water Jacketed Incubator). Before (plate $\mathrm{T}_{0}$ ) and after (plate $\mathrm{T}$ ) the addition of the samples, the cells were fixed with $50 \%$ trichloroacetic acid $\left(\right.$ Sigma $\left.{ }^{\circledR}\right)$. Cell proliferation was determined by spectrophotometric quantification $(540 \mathrm{~nm})$ of the protein content, using sulforhodamine B $\left(\right.$ Sigma $\left.^{\circledR}\right)$. The chemotherapeutic drug doxorubicin $(0.1 \mathrm{mg} / \mathrm{mg})$ was used as the positive control. Based on the concentration-response for each cell line, the $\mathrm{GI}_{50}$ (concentration of the sample necessary for $50 \%$ growth inhibition) was determined using a nonlinear regression analysis with the aid of the Origin 8.0 program (OriginLab Corporation). ${ }^{15,16}$ The assays were performed in triplicate and in two separate experiments.

\section{Cytotoxicity assay}

Cell suspensions were prepared with the RAW 264.7 macrophage line (ATTC, Manassa, VA, USA) in RPMI-1640 medium (Gibco-BRL, Grand Island, NY, 
USA) supplemented with $5 \%$ fetal bovine serum and $1 \%$ penicillin:streptomycin. The suspensions were placed in 96-well plates (100 $\mu \mathrm{l} /$ well $)$ and exposed to the extract $(125,62.5,31.25,15.63,7.8,3.91,1.95$, $0.98,0.49$ and $0.24 \mu \mathrm{g} / \mathrm{mL}$ ) diluted with $10 \%$ DMSO (Sigma-Aldrich, St. Louis, MO, USA), remaining at $37^{\circ} \mathrm{C}$ for 48 hours in a humid atmosphere with $5 \%$ $\mathrm{CO}_{2}$ (Forma Scientific ${ }^{\circledR}, \mathrm{CO}_{2}$ Water Jacketed Incubator). Before (plate $\mathrm{T}_{0}$ ) and after (plate $\mathrm{T}$ ) the addition of the samples, the cells were fixed with $50 \%$ trichloroacetic acid (Sigma ${ }^{\circledR}$ ). Cell proliferation was determined by spectrophotometric quantification $(540 \mathrm{~nm})$ of the protein content using sulforhodamine B $\left(\operatorname{Sigma}^{\circledR}\right)$. Cell viability was calculated using the following equation: cell viability $(\%)=\left(\mathrm{A}_{\text {sample }} / \mathrm{A}_{\text {control }}\right) \times 100 \%$, in which $\mathrm{A}_{\text {sample }}$ and $\mathrm{A}_{\text {control }}$ equal absorbance of the treated and untreated samples, respectively. ${ }^{15}$ The assays were performed in triplicate and in two separate experiments.

\section{Statistics}

Statistical analysis was undertaken using Statistical Package for Social Sciences software (SPSS, v. 21, IBM, Chicago IL). Data from cell viability and metabolic activity from the biofilms and from the cytotoxicity assay were analyzed through 2-way analysis of variance (2-way ANOVA) with post-hoc comparisons by Tukey tests, under $5 \%$ significance level.

\section{Results}

\section{Phytochemical characterization}

The ESI(-)-MS spectra of the G. graciliflora extract exhibited ions referring to deprotonated $[\mathrm{M}-\mathrm{H}]^{-}$ molecules: $m / z 193$, with a molecular formula compatible with $\mathrm{C}_{7} \mathrm{H}_{14} \mathrm{O}_{6}$, suggesting the presence of 3-O-methylchiro-inositol (pinitol); $m / z 593$, with a molecular formula compatible with $\mathrm{C}_{27} \mathrm{H}_{29} \mathrm{O}_{15}$, suggesting the presence of kaempferol-3-O- $\beta$-D-glucopyranosyl- $\left(6^{\prime \prime} \rightarrow 1^{\prime \prime \prime}\right)-O-\alpha$-Lrhamnopyranoside; and $m / z 609$, with a molecular formula compatible with $\mathrm{C}_{27} \mathrm{H}_{29} \mathrm{O}_{16}$, suggesting the presence of quercetin-3-O- $\beta$-D-glucopyronasyl-( $\left(6^{\prime \prime} \rightarrow 1^{\prime \prime \prime}\right)$ $O-\alpha$-L-rhamnopyranoside (rutin) (Table 1).

\section{Antimicrobial activity}

The G. graciliflora extract and its methanol fraction demonstrated moderate fungistatic activity for $C$. albicans, C. glabrata, and C. krusei. All samples tested demonstrated strong fungistatic activity for $C$. dubliniensis, based on the classification proposed by Holetz et al. ${ }^{11}$ No fungicidal activity was evidenced at any concentration tested (Table 2).

Table 1. Proposed identification of molecules and mass data for crude extract from leaves of G. graciliflora.

\begin{tabular}{|c|c|c|c|c|}
\hline Compound & $\begin{array}{l}\text { Molecular } \\
\text { formula }\end{array}$ & $\begin{array}{l}\text { Calculated } \\
(\mathrm{m} / \mathrm{z})\end{array}$ & $\begin{array}{l}\text { Experimental } \\
(\mathrm{m} / \mathrm{z})\end{array}$ & $\begin{array}{l}\text { Error } \\
\text { (ppm) }\end{array}$ \\
\hline 3-O-methyl-chiro-inositol (pinitol) & $\mathrm{C}_{7} \mathrm{H}_{13} \mathrm{O}_{6}$ & 1.930 .706 & 1.930 .714 & 3.96 \\
\hline Kaempferol-3-O- $\beta$-D-galactopyranosyl-(6"à l"')-O- $\alpha$-L-rhamnopyranoside & $\mathrm{C}_{27} \mathrm{H}_{29} \mathrm{O}_{15}$ & 5.931 .501 & 5.931 .524 & 3.85 \\
\hline Quercetin-3-O- $\beta-D$-glucopyronasyl-(6"à 1"')-O- $\alpha$-L rhamnopyranoside (rutin) & $\mathrm{C}_{27} \mathrm{H}_{29} \mathrm{O}_{16}$ & 609.145 & 609.147 & 2 \\
\hline
\end{tabular}

Table 2. Distribution of minimum inhibitory concentration and minimum fungicidal concentration of $G$. graciliflora extract and fractions according to species of Candida.

\begin{tabular}{|c|c|c|c|c|c|c|c|c|}
\hline \multirow{3}{*}{ Samples } & \multicolumn{8}{|c|}{ Yeasts $(\mu \mathrm{g} / \mathrm{mL})$} \\
\hline & \multicolumn{2}{|c|}{ C. albicans } & \multicolumn{2}{|c|}{ C. glabrata } & \multicolumn{2}{|c|}{ C. krusei } & \multicolumn{2}{|c|}{ C. dubliniensis } \\
\hline & MIC & MFC & MIC & MFC & MIC & MFC & $\mathrm{MIC}$ & MFC \\
\hline G. graciliflora & 125 & $>2000$ & 250 & $>2000$ & 125 & $>2000$ & 390.625 & $>2000$ \\
\hline Methanol fraction & 125 & $>2000$ & 250 & $>2000$ & 250 & $>2000$ & 390.625 & $>2000$ \\
\hline Methanol sub-fraction & 2000 & $>2000$ & $>2000$ & $>2000$ & 250 & $>2000$ & 78.125 & $>2000$ \\
\hline Hydromethanol fraction (50:50) & $>2000$ & $>2000$ & $>2000$ & $>2000$ & $>2000$ & $>2000$ & 31.25 & $>2000$ \\
\hline Nystatin & 0.9765 & - & 0.9765 & - & 0.9765 & - & 0.9765 & - \\
\hline
\end{tabular}




\section{Antibiofilm activity}

The concentration corresponding to MIC $\mathrm{x}$ $100(12,500 \mu \mathrm{g} / \mathrm{mL})$ was the most effective in reducing the number of viable $\mathrm{CFU} / \mathrm{mL}$ and metabolic activity of the C. albicans cells. The number of viable cells of $C$. albicans biofilm was not statistically different $(p>0.05)$ between the concentration groups and the times, but the concentration groups differed significantly $(\mathrm{p}<0.05)$ from the growth and the positives controls. For the results of the metabolic activity, all concentration groups differed significantly $(p<0.05)$ from one another, except for time (Figure 1).

\section{Antiproliferative activity}

Doxorubicin produced a cytocidal effect on all cell lines tested. The G. graciliflora extract demonstrated nonspecific cytostatic activity, inhibiting the proliferation of all tumor cell lines tested, with no evidence of cytocidal potential up to a concentration of $250 \mu \mathrm{g} / \mathrm{mL}$. The methanol fraction produced a cytostatic effect on the cell lines as well as a cytocidal effect on the M-CF7, 786-0 and NCI/ADR-RES lines. The methanol sub-fraction and hydromethanol fraction (50:50) demonstrated no cytotoxic effect on the cell lines up to a concentration of $250 \mu \mathrm{g} / \mathrm{mL}$ (Figure 2). The antiproliferative activity of the extract and its fractions was reported as $\mathrm{GI}_{50}$ (Table 3).

\section{Cytotoxicity}

The G. graciliflora extract demonstrated a non-toxic profile on RAW 264.7 macrophage cell cultures up to a concentration of $62.5 \mu \mathrm{g} / \mathrm{mL}$, with cell viability remaining higher than $80 \%$. The analysis of variance showed a statistical difference $(p<0.05)$ between the highest concentration $(125 \mu \mathrm{g} / \mathrm{mL})$ and the other concentrations (Figure 3).

\section{Discussion}

G. graciliflora has secondary metabolites that confer different pharmacological properties to the plant and justify its use in folk medicine. In the present study, the ESI-MS spectra enabled the identification of quercetin-3-O- $\beta$-D-glucopyronasyl- $\left(6^{\prime \prime} \rightarrow 1^{\prime \prime \prime}\right)-\mathrm{O}-\alpha-\mathrm{L}-$ rhamnopyranoside (rutin) and kaempferol-3-O- $\beta$-Dgalactopyranosyl- $\left(6^{\prime \prime} \rightarrow 1^{\prime \prime \prime}\right)-\mathrm{O}-\alpha$-L-rhamnopyranoside, which are compounds belonging to the flavonoid group, as 3-O-methyl-chiro-inositol (pinitol), which belongs to the class of cyclic polyols. ${ }^{17}$

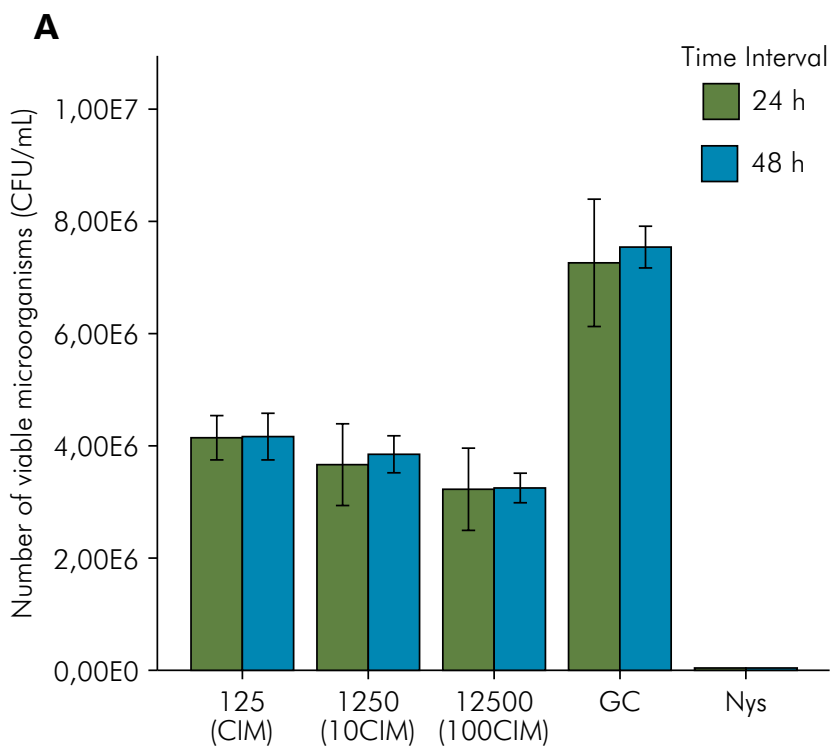

Concentration $(\mu \mathrm{g} / \mathrm{mL})$

\section{B}

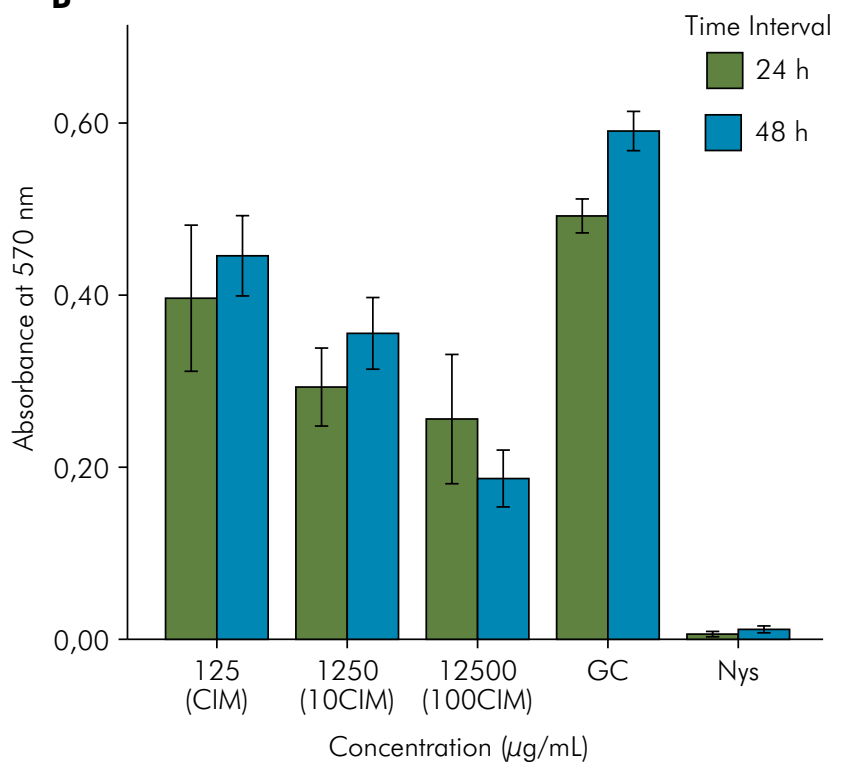

Figure 1. Cell viability and metabolic activity of C. albicans cells at 24 and 48 hours after exposure to different concentrations of extract from leaves of $\mathrm{G}$. graciliflora. 
A

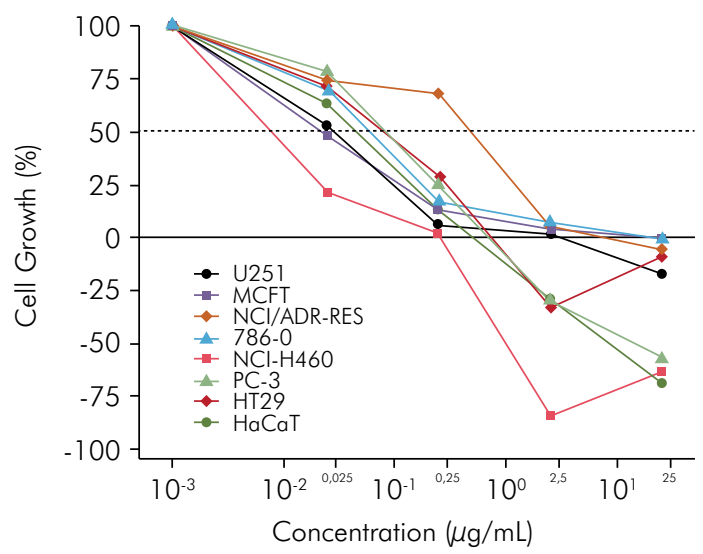

C

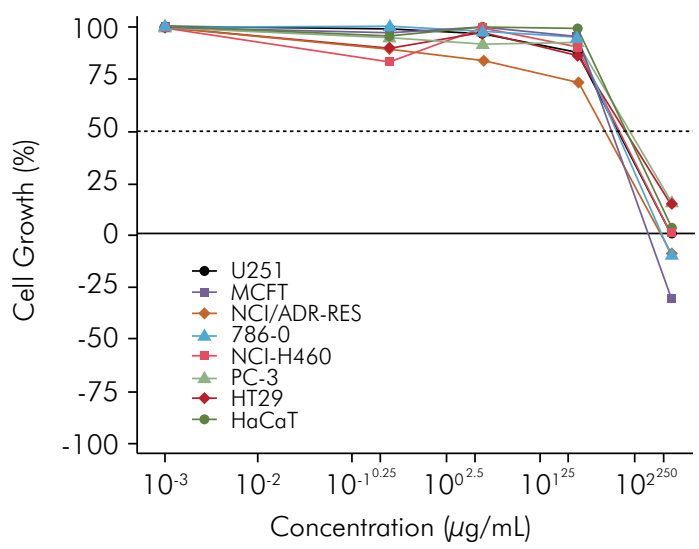

B

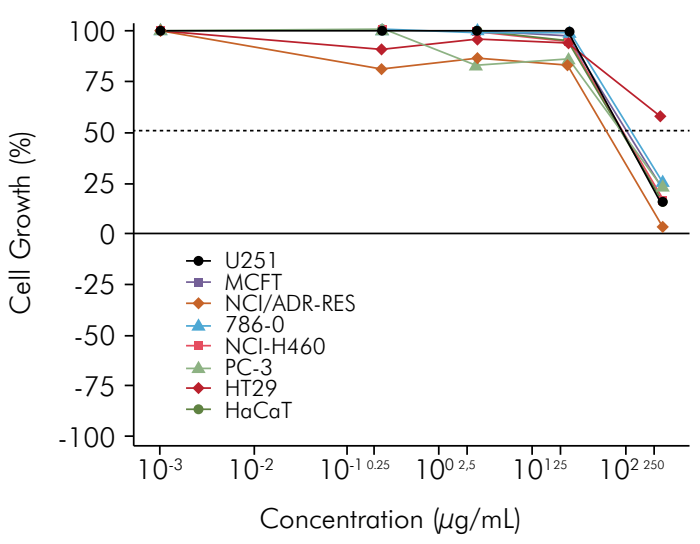

D

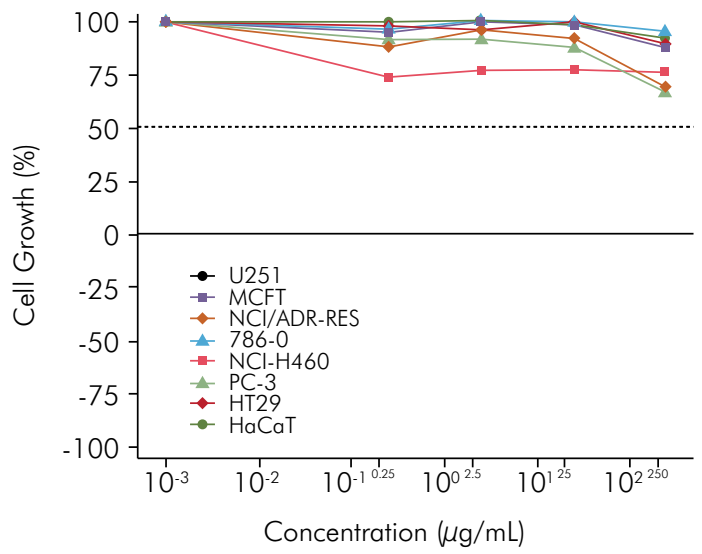

E

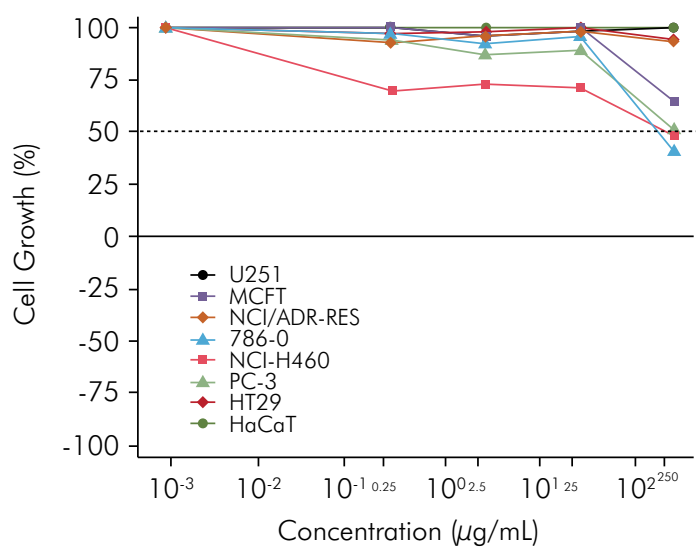

A. Exposure to chemotherapeutic drug Doxorubicin (positive control):

B. Exposure to G. graciliflora extract;

C. Exposure to methanol fraction of $G$. graciliflora extract;

D. Exposure to methanol sub-fraction of $G$. graciliflora extract;

E. Exposure to hidromethanol fraction of $G$. graciliflora extract.

Figure 2. Proliferation of cell lines as a function of concentration $(0.25,2.5,25$ and $250 \mu \mathrm{g} / \mathrm{mL})$ after 48 hours according to treatment.

Flavonoids present different pharmacological properties, including antimicrobial and antioxidant activities. These compounds can inactivate enzymes and form complexes with proteins in the cell wall of 
Table 3. Growth Inhibition 50 (GI50) (sample concentration necessary for $50 \%$ cell growth inhibition) of G. graciliflora and fractions for cultures of human tumor cell lines.

\begin{tabular}{|c|c|c|c|c|c|}
\hline \multirow{2}{*}{ Lines } & \multicolumn{5}{|c|}{$\mathrm{Gl}_{50}(\mu \mathrm{g} / \mathrm{mL})$} \\
\hline & Doxorubicin & G. graciliflora & Methanol fraction & Methanol sub-fraction & Hydromethanol fraction (50:50) \\
\hline $\begin{array}{l}\text { U251 } \\
\text { Glioma }\end{array}$ & 0.03 & 211.32 & 40.56 & $>250$ & $>250$ \\
\hline $\begin{array}{l}\text { MCF-7 } \\
\text { Breast }\end{array}$ & $<0.025$ & 142.08 & 33.64 & $>250$ & $>250$ \\
\hline $\begin{array}{l}\mathrm{NCl}-\mathrm{ADR} / \mathrm{RES} \\
\text { Resistant ovary }\end{array}$ & 0.36 & 52.57 & 28.55 & $>250$ & $>250$ \\
\hline $\begin{array}{l}786-0 \\
\text { Kidney }\end{array}$ & 0.06 & 160.23 & 33.19 & $>250$ & 195.64 \\
\hline $\begin{array}{l}\mathrm{NCl}-\mathrm{H} 460 \\
\text { Lung }\end{array}$ & $<0.025$ & 105.18 & 52.72 & $>250$ & $>250$ \\
\hline $\begin{array}{l}\text { PC-3 } \\
\text { Prostate }\end{array}$ & 0.08 & 95.92 & 95.41 & $>250$ & $>250$ \\
\hline $\begin{array}{l}\text { HT-29 } \\
\text { Colon }\end{array}$ & 0.07 & $>250$ & 78.84 & $>250$ & $>250$ \\
\hline $\begin{array}{l}\text { HaCat } \\
\text { Keratinocyte }\end{array}$ & 0.04 & 109.06 & 92.74 & $>250$ & $>250$ \\
\hline Mean log $G I_{50}$ & $<-1.03$ & $>2.16$ & 1.71 & $>2.39$ & $>2.38$ \\
\hline
\end{tabular}

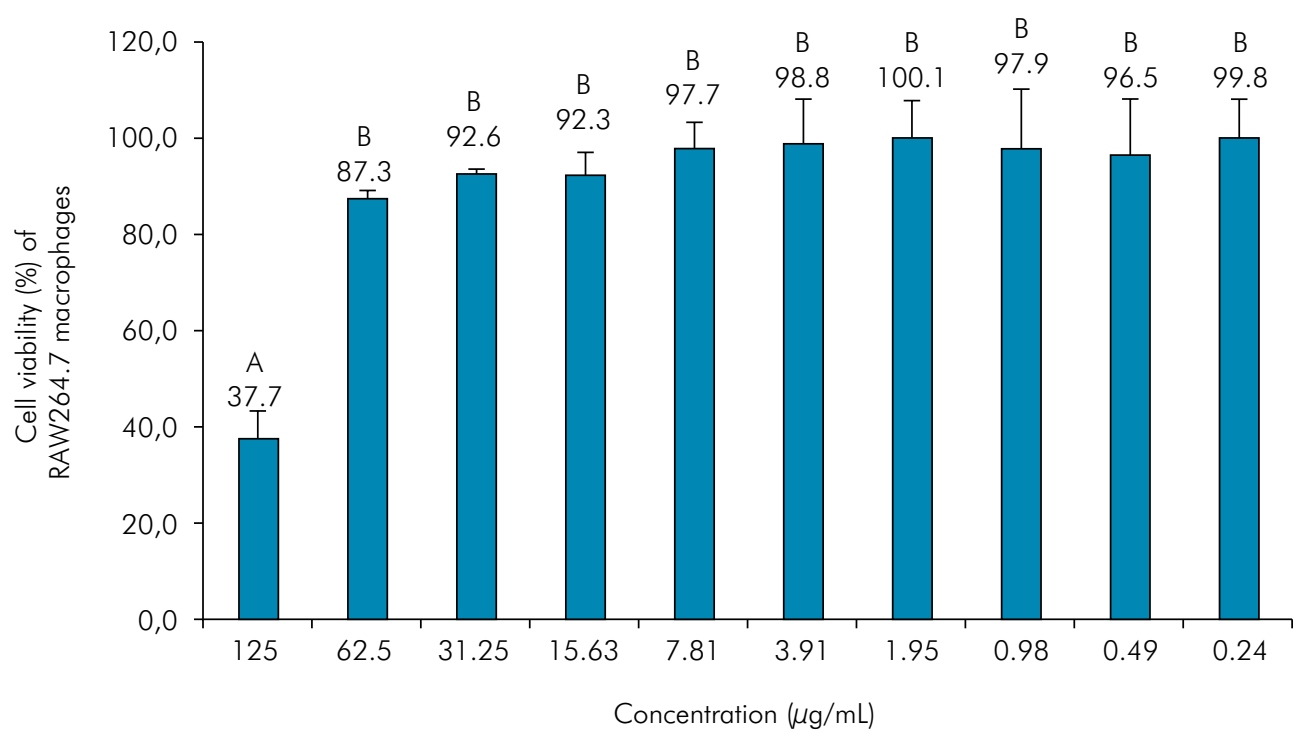

Figure 3. Percentage of cell viability of RAW 264.7 macrophage line according different concentrations of G. graciliflora leaves extract.

microorganisms, which are the probable mechanisms of antimicrobial action..$^{18}$ Moreover, flavonoids have strong antioxidant action, which explains the capacity to regulate the immune system. ${ }^{19}$

Rutin and kaempferol are known to have antioxidant, antitumor, antimicrobial, and antiinflammatory properties. ${ }^{20}$ These compounds exhibit antimicrobial activity against Staphylococcus aureus, Escherichia coli, Enterococcus faecalis, Pseudomonas aeruginosa, Proteus mirabilis, Bacillus subtilis, and C. albicans, and present potential activity against herpes simplex virus type I as well as antiproliferative activity in the presence of hepatocellular carcinoma. ${ }^{21,22}$ In turn, polyols 
are products of carbohydrate metabolism and have strong antioxidant effects. ${ }^{23}$

Considering the criteria established by Holletz et al., ${ }^{12}$ the antifungal activity of G. graciliflora was classified as moderate for C. albicans, C. krusei, and C. glabrata, and the fungistatic potential for $C$. dubliniensis was considered strong. These results are positive, as non-albican species of Candida are associated with more severe infections due to the greater resistance to available antifungal agents. ${ }^{1,4}$ The conditions and consequences of candidiasis, especially in immunocompromised patients, have led to the search for new effective treatment agents in an attempt to impede the progression of the infection (initially restricted to mucocutaneous surfaces) to more aggressive forms involving the invasion of deeper tissues and dissemination to other organs. ${ }^{24}$

The G. graciliflora extract and its fractions demonstrated a fungistatic profile, with no evidence of fungicidal capacity ( $>2000 \mu \mathrm{g} / \mathrm{mL}$ ). Thus, the extract is able to inhibit the growth of yeast without causing its death. This could be favorable in controlling infection without causing an imbalance in the normal oral microbiota, which commonly occurs with fungicidal substances. These findings may be attributed to the kaempferol and rutin in the composition of the G. graciliflora, which are known to be potent antibacterial and antifungal agents. ${ }^{25,26}$ These compounds can inactivate adhesion, transport proteins, and cause the rupture of the microbial cell. ${ }^{27}$

The reduction in the metabolism of biofilm cells treated with G. graciliflora extract, as demonstrated by the MTT assay, may be related to the reduction in the number of viable C. albicans cells,$^{28}$ generally presenting proportional profiles. ${ }^{29}$ The cell number reduction $(\mathrm{CFU} / \mathrm{mL})$ and metabolic activity was greater in the biofilm treated with the extract at a concentration of $12,500 \mu \mathrm{g} / \mathrm{mL}$ after 24 and 48 hours. This may stem from the antifungal action, with the disaggregation of cells and the inhibition of adherence ability. In turn, the reduction in metabolic activity may have occurred due to intracellular stress from the action of the extract when at a higher concentration. ${ }^{28}$

The G. graciliflora extract inhibited the growth of the cell lines tested, but did not exhibit significant antiproliferative potential. According to the criteria of the US National Cancer Institute, samples with a
$\mathrm{GI}_{50}$ greater than 1.5 have no activity, those between 1.1 and 1.5 have weak anticancer activity, those between 0 and 1 have moderate activity, and those with $\log \mathrm{GI}_{50}$ less than zero have potent activity. ${ }^{30}$

The methanol fraction demonstrated cytostatic activity for the majority of cell line tested and cytocidal activity against the M-CF7 (breast), 786-0 (kidney), and $\mathrm{NCI} / A D R-R E S$ (multidrug-resistant ovary phenotype) lines, the latter of which was the most susceptible $\left(\mathrm{GI}_{50}=28.55 \mu \mathrm{g} / \mathrm{mL}\right)$. The US National Cancer Institute considers a $\mathrm{GI}_{50}$ lower than $30 \mu \mathrm{g} / \mathrm{mL}$ to be indicative of a promising extract, ${ }^{31}$ which suggests possible selectivity of this fraction for ovarian tumor cells.

The antiproliferative activity of the methanol fraction of the G. graciliflora extract against tumor cells may be associated with the presence of flavonoids. This class of compounds inhibits the effects of cancer by combating free radicals, modifying carcinogenesis-activating enzymes, and inhibiting the transcription factor of proteins activated by tumor promoting factors. ${ }^{32}$

Kaempferol has significant antiproliferative potential on uterine cancer tumor cells (SiHa and HeLa), breast cancer cells (MCF-7), stomach cancer cells (SGC-7901), and lung cancer cells (A549). ${ }^{33,34}$ The proliferation and viability of these cell lines were significantly reduced when submitted to treatment with these compounds due to the increase in intracellular calcium, nuclear condensation, DNA fragmentation, and rupture of the mitochondrial membrane, thereby inducing the mechanism of apoptosis. ${ }^{33,34}$

Pinitol is also reported to have the capacity to reduce the occurrence of metastasis in cases of lung cancer ${ }^{35}$ and prostate cancer ${ }^{36}$. This effect is suggested to be due to the reduction in RNAm and the expression of integrins, which are cell adhesion molecules that play a key role in the control of cell adhesion, migration, and differentiation, as well as in the mechanism of apoptosis, ${ }^{37}$ all of which are closely related to tumor progression and the process of metastasis. ${ }^{37}$

The cytotoxic activity of the extract was evaluated using a murine macrophage line (RAW 264.7), which is widely used in in vitro cytotoxicity studies. ${ }^{6,14,38,39}$ This is an adequate model for screening new substances with anti-inflammatory potential and for evaluating inhibitors of pathways that lead to the induction of pro-inflammatory enzymes and cytokines. ${ }^{40}$ 
According to the InternationalStandard Organization, ${ }^{41}$ concentrations that maintain cell viability lower than $70 \%$ are considered cytotoxic. In the present study, the G. graciliflora extract did not have a cytotoxic effect on the macrophages up to a concentration of $62.5 \mu \mathrm{g} / \mathrm{mL}$, as cell viability remained at $80 \%$.

The cytotoxicity results on macrophages can help define the concentrations to be used in in vitro assays of anti-inflammatory activity analyzed based on the stimulation of macrophages and the measurement of nitric oxide production. ${ }^{38}$ Nitric oxide is an important pro-inflammatory mediator in different physiological and physiopathological events. ${ }^{39}$ Agents that inhibit its production are considered as having strong anti-inflammatory potential. ${ }^{39}$

Plant extracts are investigated for different therapeutic purposes and represent an important contribution to science. Few studies have been conducted on G. graciliflora and many of the biological and pharmacological properties of the chemical

\section{References}

1. Coronado-Castellote L. Jiménez-Soriano Y. Clinical and microbiological diagnosis of oral candidiasis. J Clin Exp Dent. 2013 Dec;5(5):279-86. https://doi.org/10.4317/jced.51242

2. Ferreira GL, Pérez AL, Rocha ÍM, Pinheiro MA, Castro $\mathrm{RD}$, Carlo $\mathrm{HL}$ et al. Does scientific evidence for the use of natural products in the treatment of oral candidiasis exist? A systematic review. Evid Based Complement Alternat Med. 2015;2015:147804. https://doi.org/10.1155/2015/147804

3. Pinelli LA, Montandon AA, Corbi SC, Moraes TA, Fais LM. Ricinus communis treatment of denture stomatitis in institutionalised elderly. J Oral Rehabil. 2013 May;40(5):375-80. https://doi.org/10.1111/joor.12039

4. Silva S, Negri M, Henriques M, Oliveira R, Williams DW, Azeredo J. Candida glabrata, Candida parapsilosis and Candida tropicalis: biology, epidemiology, pathogenicity and antifungal resistance. FEMS Microbiol Rev. 2012a Mar;36(2):288-305. https://doi.org/10.1111/j.1574-6976.2011.00278.x

5. Bakhshi M, Taheri JB, Shabestari SB, Tanik A, Pahlevan R. Comparison of therapeutic effect of aqueous extract of garlic and nystatin mouthwash in denture stomatitis. Gerodontology. 2012 Jun;29(2):e680-4. https://doi.org/10.1111/j.1741-2358.2011.00544.x

6. Oliveira JR, Castro VC, Vilela PGF, Camargo SE, Carvalho $\mathrm{CA}$, Jorge $\mathrm{AO}$ et al. Cytotoxicity of Brazilian plant extracts components of this plant need to be analyzed before its putative properties can be confirmed. The results of the present study suggest that the extract from the leaves of this plant is a possible source of bioactive substances that can be used in the development of novel products for the treatment of oral candidiasis.

\section{Conclusions}

The extract from the leaves of G. graciliflora showed antifungal activity capable of inhibiting the growth of Candida species as well as the formation of C. albicans biofilm, with no evidence of a significant change in the viability of human tumor and non-tumor cell lines.

\section{Acknowledgements}

This study was supported by CNPq/CAPES ( $\left.\mathrm{N}^{\circ} 552561 / 2011-8\right)$. The authors declare that they had no competing interests with other people or organizations that could inappropriately influence their work. against oral microorganisms of interest to dentistry. BMC Complement Altern Med. 2013 Aug;13(1):208. https://doi.org/10.1186/1472-6882-13-208

7. Silva MS, Brandão DO, Chaves TP, Formiga Filho AL, Costa $E M$, Santos VL et al. Study bioprospecting of medicinal plant extracts of the semiarid northeast: contribution to the control of oral microorganisms. Evid Based Complement Alternat Med. 2012;2012:1-6. https://doi.org/10.1155/2012/681207

8. Agra MF, Silva KN, Basílio IJ, Freitas PF, Barbosa-Filho JM. Survey of medicinal plants used in the region Northeast of Brazil. Rev Bras Farmacogn. 2008 Jul/Sep;18(3):472-508. https://doi.org/10.1590/S0102-695X2008000300023

9. Coelho FB, Dal Belo CA, Lolis SF, Santos MG. Levantamento etnofarmacológico realizado na comunidade Mumbuca localizada no Jalapão - TO. Rev Eletronica Farm. 2005;2(2 supl):52-5

10. Cabral EC, Sevart L, Spindola HM, Coelho MB, Sousa IM, Queiroz NC et al. Pterodon pubescens oil: characterisation, certification of origin and quality control via mass spectrometry fingerprinting analysis. Phytochem Anal. 2013 Feb;24(2):184-92. https://doi.org/10.1002/pca.2404

11. Clinical and Laboratory Standards Institute - CLSI. Reference method for broth dilution antifungal susceptibility testing of yeasts: approved standard. 3rd ed. - Wayne: Clinical and Laboratory Standards Institute; 2008. 
12. Holetz FB, Pessini GL, Sanches NR, Cortez DA, Nakamura $C V$, Dias Filho BP. Screening of some plants used in the Brazilian folk medicine for the treatment of infectious diseases. Mem Inst Oswaldo Cruz. 2002 Oct;97(7):1027-31. https://doi.org/10.1590/S0074-02762002000700017

13. Freitas-Fernandes FS, Cavalcanti YW, Ricomini Filho AP, Silva WJ, Del Bel Cury AA, Bertolini MM. Effect of daily use of an enzymatic denture cleanser on Candida albicansbiofilms formed on polyamide and poly(methyl methacrylate) resins: an in vitro study. J Prosthet Dent. 2014 Dec;112(6):1349-55. https://doi.org/10.1016/i.prosdent.2014.07.004

14. de Oliveira JR, de Aguiar Almeida RB, das Graças Figueiredo Vilela P, de Oliveira FE, da Rocha RF, Jorge AO et al. Control of microorganisms of oral health interest with Arctium lappaL. (burdock) extract non-cytotoxic to cell culture of macrophages (RAW 264.7). Arch Oral Biol. 2014a Aug;59(8):808-14. https://doi.org/10.1016/i.archoralbio.2014.05.013

15. Monks A, Scudiero D, Skehan P, Shoemaker R, Paull K, Vistica $D$ et al. Feasibility of a high-flux anticancer drug screen using a diverse panel of cultured human tumor cell lines. J Natl Cancer Inst. 1991 Jun;83(11):757-66. https://doi.org/10.1093/inci/83.11.757

16. Shoemaker $\mathrm{RH}$. The $\mathrm{NCl} 60$ human tumour cell line anticancer drug screen. Nat Rev Cancer. 2006 Oct;6(10):813-23. https://doi.org/10.1038/nrcl951

17. Gupta B, Huang B. Mechanism of salinity tolerance in plants: physiological, biochemical and molecular characterization. Int J Genomics. 2014;2014:ID701596. https://doi.org/10.1155/2014/701596

18. Silva MJD, Endo LH, Dias ALT, Silva GA, Santos MH, Silva MA. Assessment of the antioxidant and antimicrobial activity of the organic extracts and fractions of Mimosa caesalpiniifolia Benth. (Mimosaceae). Rev CiEnc Farm Básica Apl. 2012b; 33(2):267-74.

19. Vezza T, Rodríguez-Nogales A, Algieri F, Utrilla MP, Rodriguez-Cabezas ME, Galvez J. Flavonoids in inflammatory bowel disease: a review. nutrients. 2016 Apr;8(4):211. https://doi.org/10.3390/nu8040211

20. He X, Bai Y, Zhao Z, Wang X, Fang J, Huang L et al. Local and traditional uses, phytochemistry, and pharmacology of Sophora japonica L.: a review. J Ethnopharmacol. 2016 Jul;187:160-82. https://doi.org/10.1016/i.jep.2016.04.014

21. Rashed K, Butnariu M. Antimicrobial and antioxidant activities of Bauhinia racemosaLam. and chemical content. Iran J Pharm Res. 2014;13(3):1073-80.

22. Singh G, Passsari AK, Leo VV, Mishra VK, Subbarayan $S$, Singh BP et al. Evaluation of phenolic content variability along with antioxidant, antimicrobial, and cytotoxic potential of selected traditional medicinal plants from India. Front Plant Sci. 2016 Mar;7:407. https://doi.org/10.3389/fpls.2016.00407

23. Agarie S, Kawaguchi A, Kodera A, Sunagawa H, Kojima $\mathrm{H}$, Nose $\mathrm{A}$ et al. Potential of the commonice plant, Mesembryanthemum crystallinum as a newhigh-functional food as evaluated by polyol accumulation. Plant Prod Sci. 2009 Jul;12(1):37-46. https://doi.org/10.1626/pps.12.37

24. Santos AL, Braga-Silva LA. Aspartic protease inhibitors: effective drugs against the human fungal pathogen Candida albicans. Mini Rev Med Chem. 2013 Jan;13(1):155-62. https://doi.org/10.2174/138955713804484802

25. Tatsimo SJ, Tamokou JD, Havyarimana L, Csupor D, Forgo P, Hohmann J et al. Antimicrobial and antioxidant activity of kaempferol rhamnoside derivatives from Bryophyllum pinnatum. BMC Res Notes. 2012 Mar;5(1):158. https://doi.org/10.1186/1756-0500-5-158

26. Pinho E, Ferreira IC, Barros L, Carvalho AM, Soares G, Henriques M.. Antibacterial potential of northeastern Portugal wild plant extracts and respective phenolic compounds. BioMed Res Int. 2014;2014:ID814590. https://doi.org/10.1155/2014/814590

27. Alavarce RAS, Saldanha LL, Almeida NLM, Porto VC, Dokkedal AL, Lara VS. The beneficial effect of Equisetum giganteum L. against Candida biofilm formation: new approaches to denture stomatitis. Evid Based Complement Alternat Med. 2015 2015:ID939625. http://dx.doi. org/10.1155/2015/939625

28. Basso FG, Oliveira CF, Fontana A, Kurachi C, Bagnato VS, Spolidório DM et al. In Vitro effect of low-level laser therapy on typical oral microbial biofilms. Braz Dent J. 2011;22(6):502-10. https://doi.org/10.1590/S0103-64402011000600011

29. Silva WJ, Seneviratne J, Samaranayake LP, Del Bel Cury AA. Bioactivity and architecture of Candida albicans biofilms developed on poly(methyl methacrylate) resin surface. J Biomed Mater Res B Appl Biomater. 2010 Jul;94(1):149-56. https://doi.org/10.1002/jbm.b.31635

30. Fouche G, Cragg GM, Pillay P, Kolesnikova N, Maharai VJ, Senabe J. In vitro anticancer screening of South African plants. J Ethnopharmacol. 2008 Oct;119(3):455-61. https://doi.org/10.1016/i.jep.2008.07.005

31. Suffness M, Pezzuto JM. Assays related to cancer drug discovery. In: Hostettmann K, editor. Methods in plant biochemistry: assays for bioactivity. London: Academic Press; 1990. p. 71-133.

32. Çelik H. Arinç E. Evaluation of the protective effects of Quercetin, rutin, naringenin and trolox against Idarubicininduced DNA damage. J Pharm Pharm Sci. 2010;13(2):231-41. https://doi.org/10.18433/J3S01G

33. Liao W, Chen L, Ma X, Jiao R, Li X, Wang Y. Protective effects of kaempferol against reactive oxygen speciesinduced hemolysis and its antiproliferative activity on human cancer cells. Eur J Med Chem. 2016 May;114:24-32. https://doi.org/10.1016/i.ejmech.2016.02.045

34. Tu LY, Bai HH, Cai JY, Deng SP. The mechanism of kaempferol induced apoptosis and inhibited proliferation in human cervical cancer SiHa cell: from macro to nano. Scanning. 2016 Nov;38(6):644-53. https://doi.org/10.1002/sca.21312 
35. Sethi G, Ahn KS, Sung B, Aggarwal BB. Pinitol targets nuclear factor-kappaB activation pathway leading to inhibition of gene products associated with proliferation, apoptosis, invasion, and angiogenesis. Mol Cancer Ther. 2008 Jun;7(6):1604-14. https://doi.org/10.1158/1535-7163.MCT-07-2424

36. Lin TH, Tan TW, Tsai TH, Chen CC, Hsieh TF, Lee SS et al. D-pinitol inhibits prostate cancer metastasis through inhibition of $\alpha \mathrm{V} \beta 3$ integrin by modulating FAK, c-Src and NF-кB pathways. Int J Mol Sci. 2013 May; 14(5):9790-802. https://doi.org/10.3390/ijms 14059790

37. Makrilia N, Kollias A, Manolopoulos L, Syrigos K. Cell adhesion molecules: role and clinical significance in cancer. Cancer Invest. 2009 Dec;27(10):1023-37. https://doi.org/10.3109/07357900902769749

38. de Oliveira RG, Mahon CP, Ascêncio PG, Ascêncio SD, Balogun SO, de Oliveira Martins DT. Evaluation of antiinflammatory activity of hydroethanolic extract of Dilodendron bipinnatum Radlk. J Ethnopharmacol. 2014b Aug;155(1):387-95. https://doi.org/10.1016/i.jep.2014.05.041

39. Dzoyem JP, Tsamo AT, Melong R, Mkounga P, Nkengfack AE, McGaw LJ et al. Cytotoxicity, nitric oxide and acetylcholinesterase inhibitory activity of three limonoids isolated from Trichilia welwitschii (Meliaceae). Biol Res. 2015 Oct;48(1):57. https://doi.org/10.1186/s40659-015-0049-0

40. Yang YI, Shin HC, Kim SH, Park WY, Lee KT, Choi JH. 6,6'-Bieckol, isolated from marine alga Ecklonia cava, suppressed LPS-induced nitric oxide and $P G E_{2}$ production and inflammatory cytokine expression in macrophages: the inhibition of NFKB. Int Immunopharmacol. 2012 Mar;12(3):510-7. https://doi.org/10.1016/j.intimp.2012.01.005

41. International Standard Organization - ISO. (ISO - 10993-5). Biological evaluation of medical devices - Part 5: Tests for in vitro cytotoxicity. 3rd ed. Geneva: International Standard Organization; 2009. 